\title{
Genes Associated with Thoracic Aortic Aneurysm and Dissection
} \section{An Update and Clinical Implications}

\author{
Adam J. Brownstein, BA ${ }^{1}$, Bulat A. Ziganshin, $\mathrm{MD}^{1}$, Helena Kuivaniemi, MD, PhD², \\ Simon C. Body, MD, MPH ${ }^{3}$, Allen E. Bale, $\mathrm{MD}^{4}$, John A. Elefteriades, $\mathrm{MD}^{{ }^{*}}$ \\ ${ }^{1}$ Aortic Institute at Yale-New Haven Hospital, Yale University School of Medicine, New Haven, Connecticut, USA \\ ${ }^{2}$ Division of Molecular Biology and Human Genetics, Department of Biomedical Sciences, and Department of Psychiatry, Faculty of \\ Medicine and Health Sciences, Stellenbosch University, Tygerberg, South Africa \\ ${ }^{3}$ Department of Anesthesiology, Perioperative and Pain Medicine, Brigham and Women's Hospital, Harvard Medical School, Boston, \\ Massachusetts, USA \\ ${ }^{4}$ Department of Genetics, Yale School of Medicine, New Haven, Connecticut, USA
}

\begin{abstract}
Thoracic aortic aneurysm (TAA) is a lethal disease, with a natural history of enlarging progressively until dissection or rupture occurs. Since the discovery almost 20 years ago that ascending TAAs are highly familial, our understanding of the genetics of thoracic aortic aneurysm and dissection (TAAD) has increased exponentially. At least 29 genes have been shown to be associated with the development of TAAD, the majority of which encode proteins involved in the extracellular matrix, smooth muscle cell contraction or metabolism, or the transforming growth factor- $\beta$ signaling pathway. Almost one-quarter of TAAD patients have a mutation in one of these genes. In this review, we provide a summary of TAAD-associated genes, associated clinical features of the vasculature, and implications for surgical treatment of TAAD. With the widespread use of next-generation sequencing and development of novel functional assays, the future of the genetics of TAAD is bright, as both novel TAAD genes and variants within the genes will continue to be identified.

Copyright $\odot 2017$ Science International Corp.
\end{abstract}

Key Words:

Thoracic aortic aneurysm and dissection (TAAD) • Genetics • Aortic aneurysm

Thoracic aortic aneurysms (TAAs), which have an estimated annual incidence of 10.4 per 100,000 people [1], are typically clinically silent yet potentially fatal, as their natural history is to progressively expand until dissection or rupture occurs. Our genetic understanding of thoracic aortic aneurysm and dissection (TAAD) has rapidly advanced since the identification of the FBN1 gene as the cause of Marfan syndrome in 1991 [2] and the discovery of the familial nature of TAAD in the late 1990s. While studies demonstrate that $20 \%$ of individuals with non-syndromic TAAD have a positive family history $[3,4]$, this percentage is most likely a marked underestimation, as not all family members of affected individuals undergo routine aortic imaging [5]. Of the 29 TAAD-associated genes identified to date, the majority encode proteins involved in the extracellular matrix, smooth muscle cell contraction or

* Corresponding Author:

John A. Elefteriades, MD

Aortic Institute at Yale-New Haven Hospital

Yale University School of Medicine

789 Howard Ave, Clinic Building CB317, New Haven 06519, CT, USA

Tel.: +1 203785 2551; Fax: +1 203785 3552; E-Mail: john.elefteriades@yale.edu
Fax +12037853552
E-Mail: aorta@scienceinternational.org

http://aorta.scienceinternational.org
Published by Science International Corp. ISSN 2325-4637

Accessible online at: http://aorta.scienceinternational.org 


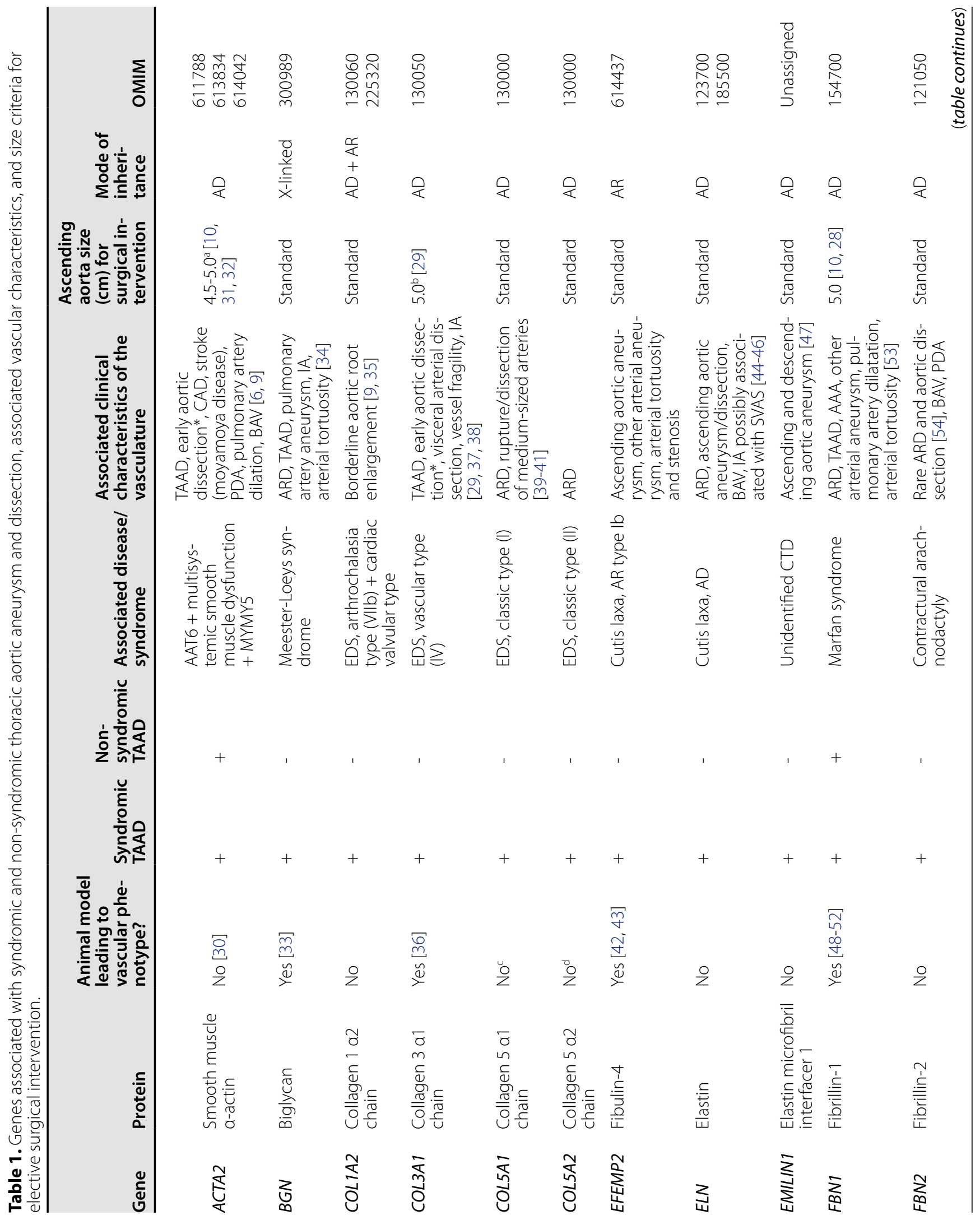




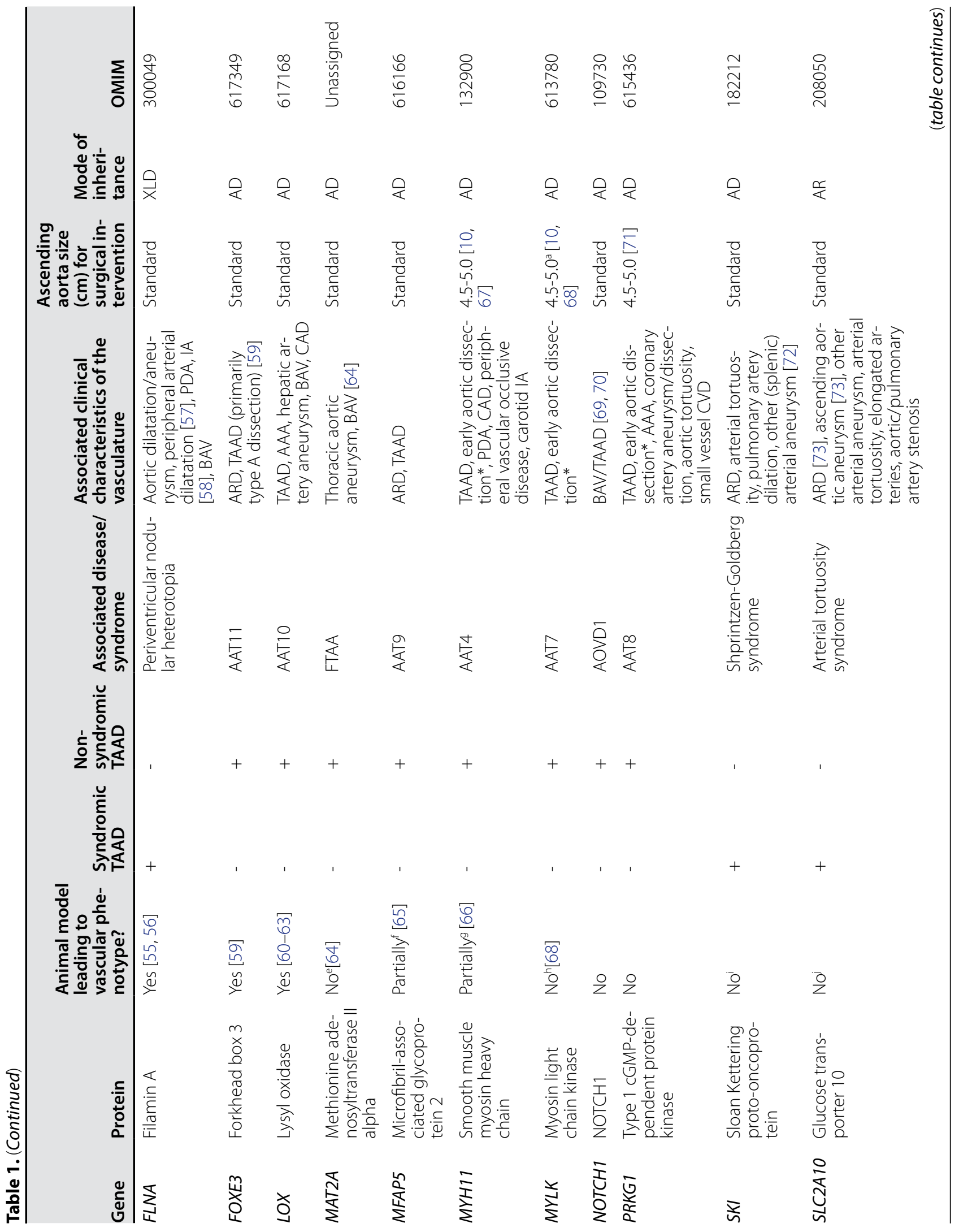




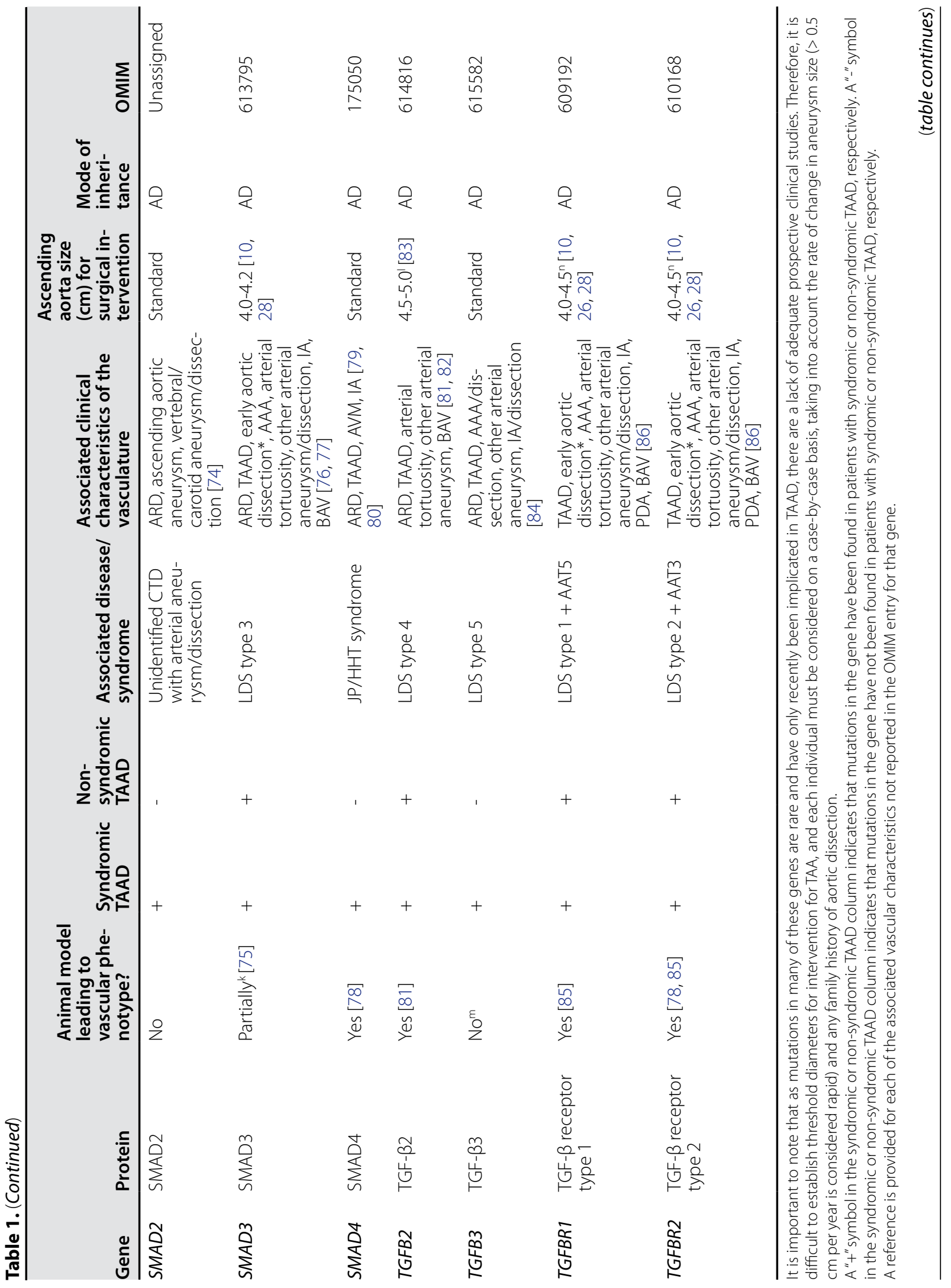




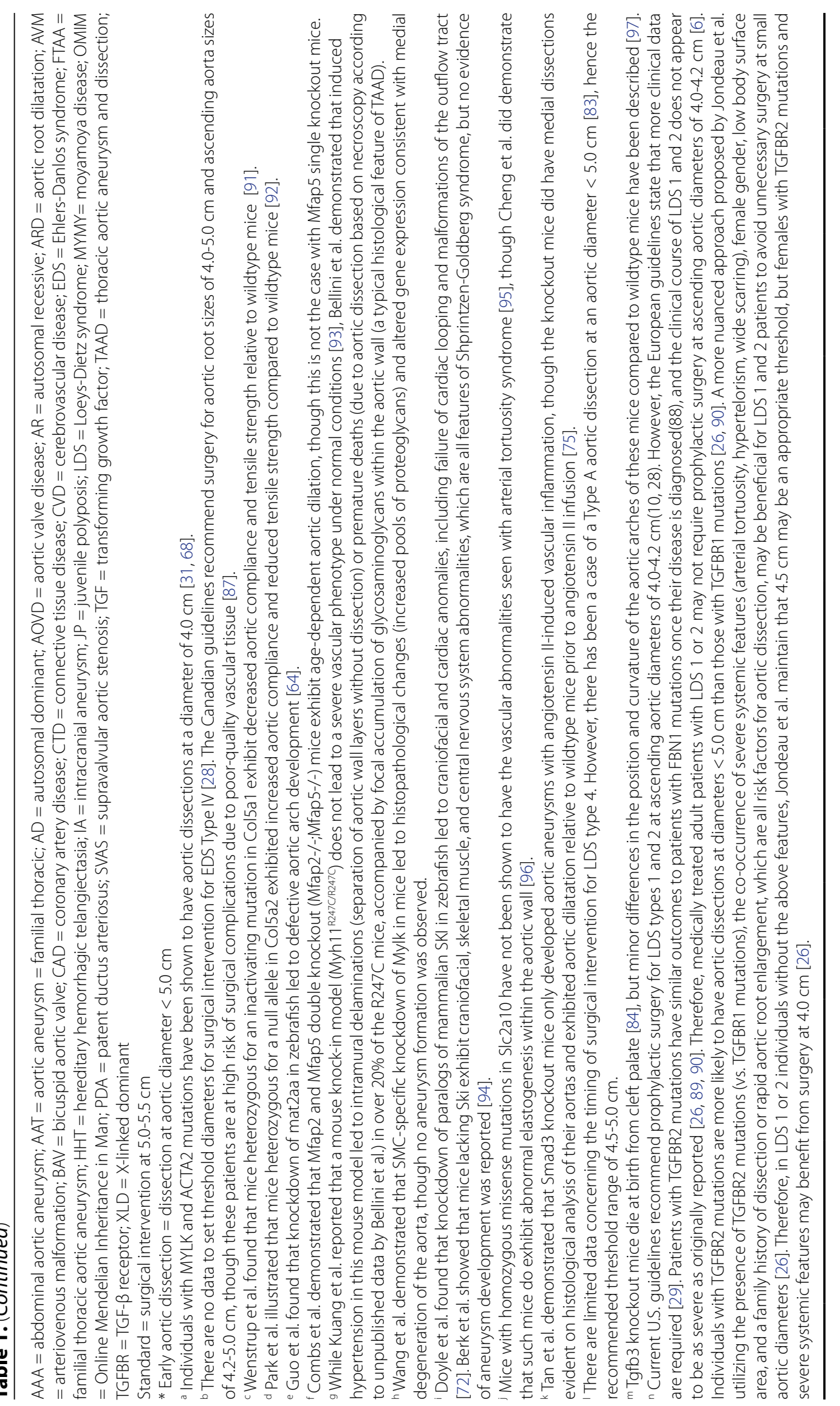


metabolism, or the transforming growth factor (TGF)- $\beta$ signaling pathway (Table 1) (reviewed in [6-14]). Almost one-quarter of patients with TAAD possess a mutation in one of these genes [6], the majority of which are inherited in an autosomal dominant fashion with reduced penetrance and variable expressivity $[15,16]$. It is of interest to note that most genetic risk factors for aneurysms in other locations of the body (e.g., in intracranial arteries or the abdominal aorta) are different from those for TAAD [17-19].

TAAD has been classified into syndromic (associated with abnormalities of other organ systems) and non-syndromic (manifestations restricted to the aorta) $[12,20]$ categories, yet there is significant overlap in the genetic basis of syndromic and non-syndromic familial TAAD. Mutations in FBN1 and Loeys-Dietz syndrome (LDS) type 1-4 genes (TGFBR1, TGFBR2, SMAD3, and TGFB2) are estimated to account for $10 \%$ of familial non-syndromic TAAD [6]. Also, mutations in ACTA2 are estimated to cause $12-21 \%$ of familial TAAD, whereas mutations in other genes may each account for only $1-2 \%$ or less of non-syndromic TAAD [6]. The identification of specific mutated genes in patients with TAAD is crucial because it permits targeted genetic testing of apparently unaffected but currently undiagnosed family members. Furthermore, genetic information helps determine the patient's risk for aortic dissection and rupture, especially mutations associated with vascular events at an ascending aorta size $<5.0$ $\mathrm{cm}$ (Figure 1), which does not usually necessitate aortic resection in the absence of such mutations, a family history of aortic dissection, or rapid aneurysmal growth ( $>0.5 \mathrm{~cm} /$ year). Identification of specific genetic variants associated with TAAD clinical outcomes may help predict how aortic disease will manifest and estimate the risk of other vascular diseases [6] (Table 1). Moreover, genotype-phenotype correlations have been established for both syndromic (FBN1, COL3A1, TGFBR1, and TGFBR2) and non-syndromic ( $A C T A 2)$ TAAD, meaning that the specific genetic variant in TAAD-affected individuals can help predict the course and severity of disease [21-27].

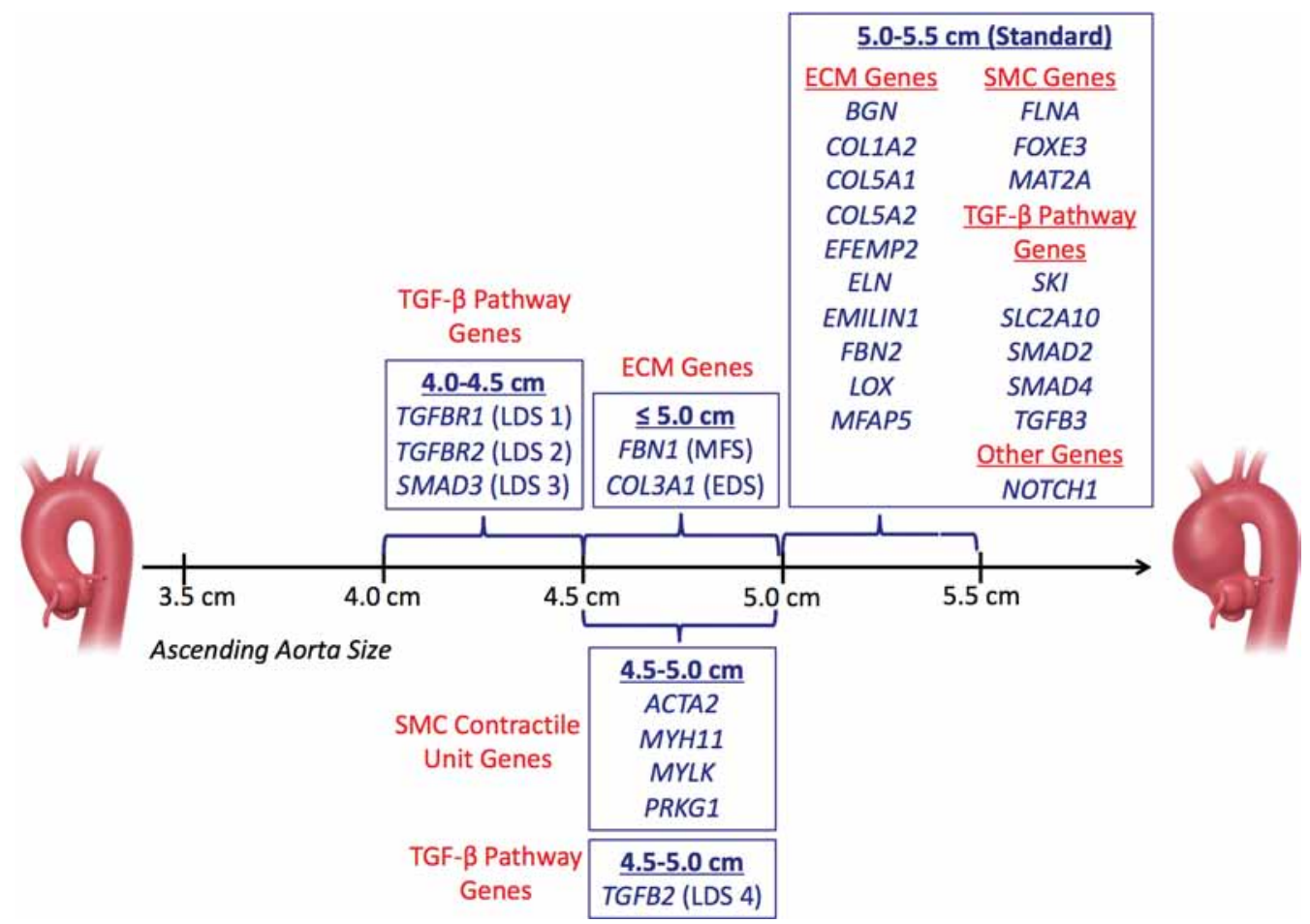

Figure 1. Simplified schematic illustration of ascending aorta dimensions for prophylactic surgical intervention divided by gene category: ECM genes, SMC contractile unit and metabolism genes, and TGF- $\beta$ signaling pathway genes (data derived from Table 1). ECM, extracellular matrix; LDS, Loeys-Dietz syndrome; MFS, Marfan syndrome; SMC, smooth muscle cell; EDS, Ehlers-Danlos syndrome. 
As stated in the most recent United States and European guidelines $[28,29]$, personalized care based on underlying genetic mutations is and will continue to be a critical aspect of high-quality patient care. As genetic testing becomes more widespread, individuals at genetic risk for TAAD may be identified earlier so that prophylactic medical and surgical intervention can be implemented to avert potentially fatal complications of TAAD. Furthermore, the utilization of next-generation sequencing could lead to the development of a comprehensive library of pathogenic genetic variants. As the genetic basis of TAAD is still a highly dynamic and burgeoning field, we present the most up-to-date list of genes associated with TAAD (Table 1). We plan to update this report annually, adding new genes, intervention criteria, and manage- ment recommendations as they become available.

\section{Acknowledgements}

AJB was supported by the Richard K. Gershon, M.D., Student Research Fellowship and the Yale University School of Medicine Medical Student Research Fellowship.

\section{Conflict of Interest}

The authors have no conflict of interest relevant to this publication.

\section{Comment on this Article or Ask a Question}

\section{References}

1. Ramanath VS, Oh JK, Sundt TM, 3rd, Eagle KA. Acute aortic syndromes and thoracic aortic aneurysm. Mayo Clinic Proc. 2009;84:465-481. DOI: 10.1016/S00256196(11)60566-1

2. Dietz HC, Cutting GR, Pyeritz RE, Maslen CL, Sakai LY, Corson GM, et al. Marfan syndrome caused by a recurrent de novo missense mutation in the fibrillin gene. Nature. 1991;352:337-339. DOI: 10.1038/352337a0

3. Biddinger $A$, Rocklin $M$, Coselli J, Milewicz DM. Familial thoracic aortic dilatations and dissections: a case control study. J Vasc Surg. 1997;25:506-511. DOI: 10.1016/ S0741-5214(97)70261-1

4. Coady MA, Davies RR, Roberts M, Goldstein LJ, Rogalski MJ, Rizzo JA, et al. Familial patterns of thoracic aortic aneurysms. Arch Surg. 1999;134:361-367. DOI: 10.1001/archsurg.134.4.361

5. Elefteriades JA, Farkas EA. Thoracic aortic aneurysm clinically pertinent controversies and uncertainties. J Am Coll Card. 2010;55:841-857. DOI: 10.1016/j. jacc.2009.08.084

6. Milewicz D, Hostetler E, Wallace S, Mellor-Crummey L, Gong L, Pannu H, et al. Precision medical and surgical management for thoracic aortic aneurysms and acute aortic dissections based on the causative mutant gene. J Cardiovasc Surg (Torino). 2016;57:172-177. PMID: 26837258

7. Karimi A, Milewicz DM. Structure of the elastin-contractile units in the thoracic aorta and how genes that cause thoracic aortic aneurysms and dissections disrupt this structure. Can J Cardiol. 2016;32:26-34.
DOI: 10.1016/j.cjca.2015.11.004

8. Isselbacher $\mathrm{EM}$, Lino Cardenas $\mathrm{CL}$, Lindsay ME. Hereditary influence in thoracic aortic aneurysm and dissection. Circulation. 2016;133:2516-2528. DOI: 10.1161/CIRCULATIONAHA. 116.009762

9. Bradley TJ, Bowdin SC, Morel CF, Pyeritz RE. The expanding clinical spectrum of extracardiovascular and cardiovascular manifestations of heritable thoracic aortic aneurysm and dissection. Can J Cardiol. 2016;32:86-99. DOI: 10.1016/j.cjca.2015.11.007

10. Andelfinger G, Loeys B, Dietz $H$. A decade of discovery in the genetic understanding of thoracic aortic disease. Can J Cardiol. 2016;32:13-25. DOI: 10.1016/j. cjca.2015.10.017

11. Luyckx I, Loeys BL. The genetic architecture of non-syndromic thoracic aortic aneurysm. Heart. 2015;101:1678-1684. DOI: 10.1136/heartjnl-2014-306381

12. Pomianowski P, Elefteriades JA. The genetics and genomics of thoracic aortic disease. Ann Cardiothorac Surg. 2013;2:271-279. DOI: 10.3978/j.issn.2225-319X.2013.05.12

13. Gillis E, Van Laer L, Loeys BL. Genetics of thoracic aortic aneurysm: at the crossroad of transforming growth factor-beta signaling and vascular smooth muscle cell contractility. Circ Res. 2013;113:327-340. DOI: 10.1161/CIRCRESAHA.113.300675

14. Elefteriades JA, Pomianowski P. Practical genetics of thoracic aortic aneurysm. Prog Cardiovasc Dis. 2013;56:57-67. DOI: 10.1016/j.pcad.2013.06.002
15. Albornoz G, Coady MA, Roberts M, Davies RR, Tranquilli M, Rizzo JA, et al. Familial thoracic aortic aneurysms and dissections - Incidence, modes of inheritance, and phenotypic patterns. Ann Thorac Surg. 2006;82:1400-1406. DOI: 10.1016/j.athoracsur.2006.04.098

16. Milewicz DM, Chen H, Park ES, Petty EM, Zaghi $H$, Shashidhar $G$, et al. Reduced penetrance and variable expressivity of familial thoracic aortic aneurysms/dissections. Am J Cardiol. 1998;82:474-479. DOI: 10.1016/S0002-9149(98)00364-6

17. Kuivaniemi $H$, Ryer EJ, Elmore JR, Tromp $\mathrm{G}$. Understanding the pathogenesis of abdominal aortic aneurysms. Expert Rev Cardiovasc Ther. 2015;13:975-987. DOI: 10.1586/14779072.2015.1074861

18. Tromp G, Weinsheimer S, Ronkainen A, Kuivaniemi $\mathrm{H}$. Molecular basis and genetic predisposition to intracranial aneurysm. Ann Med. 2014;46:597-606. DOI: 10.3109/07853890.2014.949299

19. Jones GT, Tromp G, Kuivaniemi H, Gretarsdottir S, Baas AF, Giusti B, et al. Metaanalysis of genome-wide association studies for abdominal aortic aneurysm identifies four new disease-specific risk loci. Circ Res. 2017;120:341-353. DOI: 10.1161/CIRCRESAHA.116.308765

20. El-Hamamsy I, Yacoub MH. Cellular and molecular mechanisms of thoracic aortic aneurysms. Nat Rev Cardiol. 2009;6:771786. DOI: $10.1038 /$ nrcardio.2009.191

21. Franken $R$, Groenink $M$, de Waard V, Feenstra HM, Scholte AJ, van den Berg MP, et al. Genotype impacts survival in Marfan syn- 
drome. Eur Heart J. 2016;37:3285-3290. DOI: 10.1093/eurheartj/ehv739

22. Baudhuin LM, Kotzer KE, Lagerstedt SA. Decreased frequency of FBN1 missense variants in Ghent criteria-positive Marfan syndrome and characterization of novel FBN1 variants. J Hum Genet. 2015;60: 241-252. DOI: $10.1038 /$ jhg.2015.10

23. Frank M, Albuisson J, Ranque B, Golmard L, Mazzella JM, Bal-Theoleyre L, et al. The type of variants at the COL3A1 gene associates with the phenotype and severity of vascular Ehlers-Danlos syndrome. Eur J Hum Genet. 2015;23:1657-1664. DOI: 10.1038/ejhg.2015.32

24. Shalhub S, Black JH, 3rd, Cecchi AC, Xu $\mathrm{Z}$, Griswold BF, Safi HJ, et al. Molecular diagnosis in vascular Ehlers-Danlos syndrome predicts pattern of arterial involvement and outcomes. J Vasc Surg. 2014;60:160-169. DOI: 10.1016/j. jvs.2014.01.070

25. Pepin MG, Schwarze U, Rice KM, Liu M, Leistritz D, Byers PH. Survival is affected by mutation type and molecular mechanism in vascular Ehlers-Danlos syndrome (EDS type IV). Genet Med. 2014;16:881888. DOI: $10.1038 /$ gim.2014.72

26. Jondeau G, Ropers J, Regalado E, Braverman A, Evangelista A, Teixedo G, et al. International registry of patients carrying TGFBR1 or TGFBR2 mutations: results of the MAC (Montalcino Aortic Consortium). Circ Cardiovasc Genet. 2016;9:548-558. DOI: 10.1161/CIRCGENETICS.116.001485

27. Regalado ES, Guo DC, Prakash S, Bensend TA, Flynn K, Estrera A, et al. Aortic disease presentation and outcome associated with ACTA2 mutations. Circ Cardiovasc Genet. 2015;8:457-464. DOI: 10.1161/CIRCGENETICS.114.000943

28. Hiratzka LF, Bakris GL, Beckman JA, Bersin RM, Carr VF, Casey DE Jr, et al. 2010 ACCF/ AHA/AATS/ACR/ASA/SCA/SCAI/SIR/STS/ SVM Guidelines for the diagnosis and management of patients with thoracic aortic disease. A Report of the American College of Cardiology Foundation/American Heart Association Task Force on Practice Guidelines, American Association for Thoracic Surgery, American College of Radiology, American Stroke Association, Society of Cardiovascular Anesthesiologists, Society for Cardiovascular Angiography and Interventions, Society of Interventional Radiology, Society of Thoracic Surgeons, and Society for Vascular Medicine. J Am Coll Card. 2010;55:e27-e129. DOI: 10.1016/j.jacc.2010.02.015

29. Erbel R, Aboyans V, Boileau C, Bossone E, Bartolomeo RD, Eggebrecht $\mathrm{H}$, et al. 2014 ESC Guidelines on the diagnosis and treat- ment of aortic diseases: document covering acute and chronic aortic diseases of the thoracic and abdominal aorta of the adult. The Task Force for the diagnosis and treatment of aortic diseases of the European Society of Cardiology (ESC). Eur Heart J. 2014;35:2873-2926. DOI: 10.1093/ eurheartj/ehu281

30. Schildmeyer LA, Braun R, Taffet G, Debiasi $M$, Burns AE, Bradley $A$, et al. Impaired vascular contractility and blood pressure homeostasis in the smooth muscle alpha-actin null mouse. FASEB J. 2000;14:2213-2220. DOI: 10.1096/fj.99-0927com

31. Disabella E, Grasso M, Gambarin FI, Narula $\mathrm{N}$, Dore R, Favalli V, et al. Risk of dissection in thoracic aneurysms associated with mutations of smooth muscle alpha-actin 2 (ACTA2). Heart. 2011;97:321-326. DOI: 10.1136/hrt.2010.204388

32. Guo DC, Pannu H, Tran-Fadulu V, Papke CL, Yu RK, Avidan N, et al. Mutations in smooth muscle alpha-actin (ACTA2) lead to thoracic aortic aneurysms and dissections. Nat Genet. 2007;39:1488-1493. DOI: 10.1038/ ng.2007.6

33. Heegaard AM, Corsi A, Danielsen CC, Nielsen $\mathrm{KL}$, Jorgensen $\mathrm{HL}$, Riminucci $\mathrm{M}$, et al. Biglycan deficiency causes spontaneous aortic dissection and rupture in mice. Circulation. 2007;115:2731-2738. DOI: 10.1161/CIRCULATIONAHA.106.653980

34. Meester JA, Vandeweyer G, Pintelon I, Lammens $M$, Van Hoorick L, De Belder S, et al. Loss-of-function mutations in the X-linked biglycan gene cause a severe syndromic form of thoracic aortic aneurysms and dissections. Genet Med. 2017;19:386-395. DOI: $10.1038 / \mathrm{gim} .2016 .126$

35. Schwarze U, Hata R, McKusickVA, Shinkai H, Hoyme HE, Pyeritz RE, et al. Rare autosomal rec[\{AU: Please confirm or correct the conflict of interest statement. \}] ]essive cardiac valvular form of Ehlers-Danlos syndrome results from mutations in the $\mathrm{COL} 1 \mathrm{~A} 2$ gene that activate the nonsense-mediated RNA decay pathway. Am J Hum Genet. 2004;74:917-930. DOI: 10.1086/420794

36. Smith LB, Hadoke PW, Dyer E, Denvir MA, Brownstein D, Miller $E$, et al. Haploinsufficiency of the murine Col3a1 locus causes aortic dissection: a novel model of the vascular type of Ehlers-Danlos syndrome. Cardiovasc Res. 2011;90:182-190. DOI: 10.1093/cvr/cvq356

37. De Paepe A, Malfait F. The Ehlers-Danlos syndrome, a disorder with many faces. Clin Genet. 2012;82:1-11. DOI: 10.1111/j.13990004.2012.01858.x

38. Germain DP. Ehlers-Danlos syndrome type IV. Orphanet J Rare Dis. 2007;2:32. DOI:
10.1186/1750-1172-2-32

39. Monroe GR, Harakalova M, van der Crabben SN, Majoor-Krakauer D, Bertoli-Avella AM, Moll FL, et al. Familial Ehlers-Danlos syndrome with lethal arterial events caused by a mutation in COL5A1. Am J Med Genet A. 2015;167:1196-1203. DOI: 10.1002/ajmg.a.36997

40. Mehta S, Dhar SU, Birnbaum Y. Common iliac artery aneurysm and spontaneous dissection with contralateral iatrogenic common iliac artery dissection in classic Ehlers-Danlos syndrome. Int J Angiol. 2012;21:167-170. DOI: 10.1055/s-00321325118

41. Wenstrup RJ, Meyer RA, Lyle JS, Hoechstetter L, Rose PS, Levy HP, et al. Prevalence of aortic root dilation in the Ehlers-Danlos syndrome. Genet Med. 2002;4:112-117. DOI: 10.109700125817-200205000-00003

42. Huang J, Davis EC, Chapman SL, Budatha M, Marmorstein LY, Word RA, et al. Fibulin-4 deficiency results in ascending aortic aneurysms: a potential link between abnormal smooth muscle cell phenotype and aneurysm progression. Circ Res. 2010;106:583-592. DOI: 10.1161/CIRCRESAHA.109.207852

43. Igoucheva $O$, Alexeev V, Halabi CM, Adams SM, Stoilov I, Sasaki T, et al. Fibulin-4 E57K knock-in mice recapitulate cutaneous, vascular and skeletal defects of recessive cutis laxa 1B with both elastic fiber and collagen fibril abnormalities. J Biol Chem. 2015;290:21443-21459. DOI: 10.1074/jbc. M115.640425

44. Jelsig AM, Urban Z, Hucthagowder V, Nissen $\mathrm{H}$, Ousager LB. Novel ELN mutation in a family with supravalvular aortic stenosis and intracranial aneurysm. Eur J Med Genet. 2017;60:110-113. DOI: 10.1016/j. ejmg.2016.11.004

45. Callewaert B, Renard M, Hucthagowder V, Albrecht B, Hausser I, Blair E, et al. New insights into the pathogenesis of autosomal-dominant cutis laxa with report of five ELN mutations. Hum Mutat. 2011;32:445455. DOI: 10.1002/humu.21462

46. Szabo Z, Crepeau MW, Mitchell AL, Stephan MJ, Puntel RA, Yin Loke K, et al. Aortic aneurysmal disease and cutis laxa caused by defects in the elastin gene. J Med Genet. 2006;43:255-258. DOI: 10.1136/jmg.2005.034157

47. Capuano A, Bucciotti F, Farwell KD, Tippin DB, Mroske C, Hulick PJ, et al. Diagnostic exome sequencing identifies a novel gene, EMILIN1, associated with autosomaldominant hereditary connective tissue disease. Hum Mutat. 2016;37:84-97. DOI: 10.1002/humu.22920 
48. Pereira L, Andrikopoulos K, Tian J, Lee SY, Keene DR, Ono R, et al. Targetting of the gene encoding fibrillin-1 recapitulates the vascular aspect of Marfan syndrome. Nat Genet. 1997;17:218-222. DOI: 10.1038/ ng1097-218

49. Pereira L, Lee SY, Gayraud B, Andrikopoulos K, Shapiro SD, Bunton T, et al. Pathogenetic sequence for aneurysm revealed in mice underexpressing fibrillin-1. Proc Natl Acad Sci USA. 1999;96:3819-3823. DOI: 10.1073/ pnas.96.7.3819

50. Judge DP, Biery NJ, Keene DR, Geubtner J, Myers L, Huso DL, et al. Evidence for a critical contribution of haploinsufficiency in the complex pathogenesis of Marfan syndrome. J Clin Invest. 2004;114:172-181. DOI: $10.1172 / J C I 20641$

51. Habashi JP, Judge DP, Holm TM, Cohn RD, Loeys BL, Cooper TK, et al. Losartan, an AT1 antagonist, prevents aortic aneurysm in a mouse model of Marfan syndrome. Science. 2006;312:117-1121. DOI: 10.1126/ science. 1124287

52. Lima BL, Santos EJ, Fernandes GR, Merkel C, Mello MR, Gomes JP, et al. A new mouse model for marfan syndrome presents phenotypic variability associated with the genetic background and overall levels of FBN1 expression. PloS ONE. 2010;5:e14136. DOI: 10.1371/journal.pone.0014136

53. Morris SA, Orbach DB, Geva T, Singh MN, Gauvreau K, Lacro RV. Increased vertebral artery tortuosity index is associated with adverse outcomes in children and young adults with connective tissue disorders. Circulation. 2011;124:388-396. DOI: 10.1161/CIRCULATIONAHA.110.990549

54. Takeda N, Morita H, Fujita D, Inuzuka R, Taniguchi $Y$, Imai $Y$, et al. Congenital contractural arachnodactyly complicated with aortic dilatation and dissection: case report and review of literature. Am J Med Genet A. 2015;167A:2382-2387. DOI: 10.1002/ajmg. a.37162

55. Retailleau K, Arhatte M, Demolombe S, Jodar $M$, Baudrie $V$, Offermanns $S$, et al. Smooth muscle filamin A is a major determinant of conduit artery structure and function at the adult stage. Pflugers Arch. 2016;468:1151-1160. DOI: 10.1007/ s00424-016-1813-x

56. Feng Y, Chen MH, Moskowitz IP, Mendonza AM, Vidali L, Nakamura F, et al. Filamin A (FLNA) is required for cell-cell contact in vascular development and cardiac morphogenesis. Proc Natl Acad Sci USA. 2006;103:19836-19841. DOI: 10.1073/ pnas.0609628104

57. Reinstein E, Frentz S, Morgan T, GarcíaMiñaúr S, Leventer RJ, McGillivray G, et al.
Vascular and connective tissue anomalies associated with X-linked periventricular heterotopia due to mutations in Filamin A. Eur J Hum Genet. 2013;21:494-502. DOI: 10.1038/ejhg.2012.209

58. Lange M, Kasper B, Bohring A, Rutsch F, Kluger $G$, Hoffjan $S$, et al. 47 patients with FLNA associated periventricular nodular heterotopia. Orphanet J Rare Dis. 2015;10:134. DOI: 10.1186/s13023-0150331-9

59. Kuang SQ, Medina-Martinez O, Guo DC, Gong L, Regalado ES, Reynolds $\mathrm{CL}$, et al. FOXE3 mutations predispose to thoracic aortic aneurysms and dissections. J Clin Invest. 2016;126:948-961. DOI: 10.1172/ JCl83778

60. Lee VS, Halabi CM, Hoffman EP, Carmichael N, Leshchiner I, Lian CG, et al. Loss of function mutation in LOX causes thoracic aortic aneurysm and dissection in humans. Proc Natl Acad Sci USA. 2016;113: 8759-8764. DOI: 10.1073/pnas.1601442113

61. Hornstra IK, Birge S, Starcher B, Bailey AJ, Mecham RP, Shapiro SD. Lysyl oxidase is required for vascular and diaphragmatic development in mice. J Biol Chem. 2003;278:14387-14393. DOI: 10.1074/jbc. M210144200

62. Maki JM, Rasanen J, Tikkanen H, Sormunen R, Makikallio K, Kivirikko Kl, et al. Inactivation of the lysyl oxidase gene Lox leads to aortic aneurysms, cardiovascular dysfunction, and perinatal death in mice. Circulation. 2002;106:2503-2509. DOI: 10.1161/01. CIR.0000038109.84500.1E

63. Ren W, Liu Y, Wang X, Jia L, Piao C, Lan F, et al. $\beta$-Aminopropionitrile monofumarate induces thoracic aortic dissection in C57BL/6 mice. Sci Rep. 2016;6:28149. DOI: 10.1038/srep28149

64. Guo DC, Gong L, Regalado ES, SantosCortez RL, Zhao R, Cai B, et al. MAT2A mutations predispose individuals to thoracic aortic aneurysms. Am J Hum Genet. 2015;96:170-177. DOI: 10.1016/j. ajhg.2014.11.015

65. Combs MD, Knutsen RH, Broekelmann TJ, Toennies HM, Brett TJ, Miller CA, et al. Microfibril-associated glycoprotein 2 (MAGP2) loss of function has pleiotropic effects in vivo. J Biol Chem. 2013;288:2886928880. DOI: 10.1074/jbc.M113.497727

66. Bellini C, Wang S, Milewicz DM, Humphrey JD. Myh11(R247C/R247C) mutations increase thoracic aorta vulnerability to intramural damage despite a general biomechanical adaptivity. J Biomech. 2015;48:113-121. DOI: 10.1016/j.jbiomech.2014.10.031

67. Pannu H, Tran-Fadulu V, Papke CL, Scherer
S, Liu Y, Presley C, et al. MYH11 mutations result in a distinct vascular pathology driven by insulin-like growth factor 1 and angiotensin II. Hum Mol Genet. 2007;16:2453-2462. DOI: $10.1093 / \mathrm{hmg} /$ ddm201

68. Wang L, Guo DC, Cao J, Gong L, Kamm KE, Regalado $\mathrm{E}$, et al. Mutations in myosin light chain kinase cause familial aortic dissections. Am J Hum Genet. 2010;87:701-707. DOI: 10.1016/j.ajhg.2010.10.006

69. McKellar SH, Tester DJ, Yagubyan M, Majumdar R, Ackerman MJ, Sundt TM, 3rd. Novel NOTCH1 mutations in patients with bicuspid aortic valve disease and thoracic aortic aneurysms. J Thorac Cardiovasc Surg. 2007;134:290-296. DOI: 10.1016/j. jtcvs.2007.02.041

70. Proost D, Vandeweyer G, Meester JA, Salemink $S$, Kempers $M$, Ingram $C$, et al. Performant mutation identification using targeted next-generation sequencing of 14 thoracic aortic aneurysm genes. Hum Mutat. 2015;36:808-814. DOI: 10.1002/ humu.22802

71. Guo DC, Regalado E, Casteel DE, SantosCortez RL, Gong L, Kim JJ, et al. Recurrent gain-of-function mutation in PRKG1 causes thoracic aortic aneurysms and acute aortic dissections. Am J Hum Genet. 2013;93:398404. DOI: 10.1016/j.ajhg.2013.06.019

72. Doyle AJ, Doyle JJ, Bessling SL, Maragh S, Lindsay ME, Schepers $D$, et al. Mutations in the TGF-beta repressor SKI cause Shprintzen-Goldberg syndrome with aortic aneurysm. Nat Genet. 2012;44:1249-1254. DOI: 10.1038/ng.2421

73. Callewaert BL, Willaert A, Kerstjens-Frederikse WS, De Backer J, Devriendt K, Albrecht $B$, et al. Arterial tortuosity syndrome: clinical and molecular findings in 12 newly identified families. Hum Mutat. 2008;29:150-158. DOI: 10.1002/humu.20623

74. Micha D, Guo DC, Hilhorst-Hofstee Y, van Kooten F, Atmaja D, Overwater $E$, et al. SMAD2 mutations are associated with arterial aneurysms and dissections. Hum Mutat. 2015;36:1145-1149. DOI: 10.1002/ humu.22854

75. Tan CK, Tan EH, Luo B, Huang CL, Loo JS, Choong $C$, et al. SMAD3 deficiency promotes inflammatory aortic aneurysms in angiotensin II-infused mice via activation of iNOS. J Am Heart Assoc. 2013;2:e000269. DOI: 10.1161/JAHA.113.000269

76. van der Linde $D$, van de Laar IM, Bertoli-Avella $A M$, Oldenburg RA, Bekkers JA, Mattace-Raso FU, et al. Aggressive cardiovascular phenotype of aneurysms-osteoarthritis syndrome caused by pathogenic SMAD3 variants. J Am Coll Cardiol. 2012;60:397- 
403. DOI: 10.1016/j.jacc.2011.12.052

77. van de Laar IM, van der Linde D, Oei EH, Bos PK, Bessems JH, Bierma-Zeinstra SM, et al. Phenotypic spectrum of the SMAD3-related aneurysms-osteoarthritis syndrome. J Med Genet. 2012;49:47-57. DOI: 10.1136/ jmedgenet-2011-100382

78. Zhang P, Hou S, Chen J, Zhang J, Lin F, Ju R, et al. SMAD4 deficiency in smooth muscle cells initiates the formation of aortic aneurysm. Circ Res. 2016;118:388-399. DOI: 10.1161/CIRCRESAHA.115.308040

79. Heald B, Rigelsky C, Moran R, LaGuardia L, O'Malley M, Burke CA, et al. Prevalence of thoracic aortopathy in patients with juvenile Polyposis Syndrome-Hereditary Hemorrhagic Telangiectasia due to SMAD4. Am J Med Genet A. 2015;167A:1758-1762. DOI: 10.1002/ajmg.a.37093

80. Wain KE, Ellingson MS, McDonald J, Gammon A, Roberts M, Pichurin P, et al. Appreciating the broad clinical features of SMAD4 mutation carriers: a multicenter chart review. Genet Med. 2014;16:588-593. DOI: $10.1038 /$ gim.2014.5

81. Lindsay ME, Schepers D, Bolar NA, Doyle JJ, Gallo E, Fert-Bober J, et al. Loss-of-function mutations in TGFB2 cause a syndromic presentation of thoracic aortic aneurysm. Nat Genet. 2012;44:922-927. DOI: 10.1038/ ng.2349

82. Boileau C, Guo DC, Hanna N, Regalado ES, Detaint D, Gong $L$, et al. TGFB2 mutations cause familial thoracic aortic aneurysms and dissections associated with mild systemic features of Marfan syndrome. Nat Genet. 2012;44:916-921. DOI: 10.1038/ ng. 2348

83. Renard M, Callewaert B, Malfait F, Campens $L$, Sharif $S$, del Campo $M$, et al. Thoracic aortic-aneurysm and dissection in association with significant mitral valve disease caused by mutations in TGFB2. Int J Card. 2013;165:584-587. DOI: 10.1016/j. ijcard.2012.09.029

84. Bertoli-Avella AM, Gillis $E$, Morisaki $H$, Verhagen JM, de Graaf BM, van de Beek G, et al. Mutations in a TGF-beta ligand, TGFB3, cause syndromic aortic aneurysms and dissections. J Am Coll Cardiol. 2015;65:13241336. DOI: 10.1016/j.jacc.2015.01.040
85. Gallo EM, Loch DC, Habashi JP, Calderon JF, Chen Y, Bedja D, et al. Angiotensin II-dependent TGF-beta signaling contributes to Loeys-Dietz syndrome vascular pathogenesis. J Clin Invest. 2014;124:448-460. DOI: $10.1172 / \mathrm{JCl} 69666$

86. MacCarrick G, Black JH, 3rd, Bowdin S, ElHamamsy I, Frischmeyer-Guerrerio PA, Guerrerio AL, et al. Loeys-Dietz syndrome: a primer for diagnosis and management. Genet Med. 2014;16:576-587. DOI: 10.1038/gim.2014.11

87. Boodhwani M, Andelfinger G, Leipsic J, Lindsay T, McMurtry MS, Therrien J, et al. Canadian Cardiovascular Society position statement on the management of thoracic aortic disease. Can J Cardiol. 2014;30:577589. DOI: 10.1016/j.cjca.2014.02.018

88. Attias D, Stheneur C, Roy C, Collod-Beroud G, Detaint D, Faivre L, et al. Comparison of clinical presentations and outcomes between patients with TGFBR2 and FBN1 mutations in Marfan syndrome and related disorders. Circulation. 2009;120:2541-2549. DOI: 10.1161/CIRCULATIONAHA.109.887042

89. Teixido-Tura G, Franken R, Galuppo V, Gutierrez Garcia-Moreno L, Borregan M, Mulder BJ, et al. Heterogeneity of aortic disease severity in patients with Loeys-Dietz syndrome. Heart. 2016;102:626-632. DOI: 10.1136/heartjnl-2015-308535

90. Tran-Fadulu V, Pannu H, Kim DH, Vick GW, 3rd, Lonsford CM, Lafont AL, et al. Analysis of multigenerational families with thoracic aortic aneurysms and dissections due to TGFBR1 or TGFBR2 mutations. J Med Genet. 2009;46:607-613. DOI: 10.1136/ jmg.2008.062844

91. Wenstrup RJ, Florer JB, Davidson JM, Phillips CL, Pfeiffer BJ, Menezes DW, et al. Murine model of the Ehlers-Danlos syndrome. col5a1 haploinsufficiency disrupts collagen fibril assembly at multiple stages. J Biol Chem. 2006;281:12888-12895. DOI: 10.1074/jbc.M511528200

92. Park AC, Phillips CL, Pfeiffer FM, Roenneburg DA, Kernien JF, Adams SM, et al. Homozygosity and heterozygosity for null COL5A2 alleles produce embryonic lethality and a novel classic Ehlers-Danlos syndrome-related phenotype. Am J Pathol. 2015;185:2000-2011. DOI: 10.1016/j.ajpath.2015.03.022

93. Kuang SQ, Kwartler CS, Byanova $\mathrm{KL}$, Pham J, Gong L, Prakash SK, et al. Rare, nonsynonymous variant in the smooth muscle-specific isoform of myosin heavy chain, MYH11, R247C, alters force generation in the aorta and phenotype of smooth muscle cells. Circ Res. 2012;110:1411-1422. DOI: 10.1161/CIRCRESAHA.111.261743

94. Berk M, Desai SY, Heyman HC, Colmenares C. Mice lacking the SKI proto-oncogene have defects in neurulation, craniofacial, patterning, and skeletal muscle development. Genes Dev. 1997;11:2029-2039. DOI: 10.1101/gad.11.16.2029

95. Zoppi N, Chiarelli N, Cinquina V, Ritelli M, Colombi M. GLUT10 deficiency leads to oxidative stress and non-canonical alphavbeta3 integrin-mediated TGFbeta signalling associated with extracellular matrix disarray in arterial tortuosity syndrome skin fibroblasts. Hum Mol Genet. 2015;24:67696787. DOI: $10.1093 / \mathrm{hmg} / \mathrm{ddv} 382$

96. Cheng $\mathrm{CH}$, Kikuchi T, Chen $\mathrm{YH}$, Sabbagha NG, Lee YC, Pan HJ, et al. Mutations in the SLC2A10 gene cause arterial abnormalities in mice. Cardiovasc Res. 2009;81:381-388. DOI: $10.1093 / c v r / c v n 319$

97. Azhar M, Schultz JJ, Grupp I, Dorn GW, 2nd, Meneton P, Molin DG, et al. Transforming growth factor beta in cardiovascular development and function. Cytokine Growth Factor Rev. 2003;14:391-407. DOI: 10.1016/ S1359-6101(03)00044-3

Cite this article as: Brownstein $\mathrm{AJ}$, Ziganshin BA, Kuivaniemi H, Body SC, Bale AE, Elefteriades JA. Genes Associated with Thoracic Aortic Aneurysm and Dissection. AORTA (Stamford). 2017;5(1): 11-20. DOI: http://dx.doi.org/10.12945/j. aorta.2017.17.003 